\title{
Analysis of Wheat Value Chain in Denaba Kebele, Dodola Districts West Arsi Zone, Oromia Region, Ethiopia
}

\author{
Abdirazak Abdala Ulisido ${ }^{1}$, Alemayehu Abebe ${ }^{2}$ \\ ${ }^{1}$ Department of Rural Development and Agricultural Extension, Jimma University College of Agriculture and Veterinary Medicine, Jimma, \\ Ethiopia \\ ${ }^{2}$ Southern Agricultural Research Institute, Areka Agricultural Research Center, Hawassa, Ethiopia
}

Email address:

abdirazak361@gmail.com (A. A. Ulisido)

\section{To cite this article:}

Abdirazak Abdala Ulisido, Alemayehu Abebe. Analysis of Wheat Value Chain in Denaba Kebele, Dodola Districts West Arsi Zone, Oromia Region, Ethiopia. International Journal of Food Engineering and Technology. Vol. 4, No. 2, 2020, pp. 36-45.

doi: $10.11648 /$ j.jifet.20200402.15

Received: October 10, 2019; Accepted: October 31, 2019; Published: September 16, 2020

\begin{abstract}
Ethiopia is the $2^{\text {nd }}$ largest wheat producers in Sub-Saharan Africa next to South Africa, with a potential expansion to 1.3 million hectare. The highlands of the central, south-eastern and northwest parts of the country are the main wheat producing areas especially west Arsi zone including Deneba Kebele. The wheat commodity selected based on uses of Food security, Environmental sustainability, Production potential, Market demand, Gender mainstreaming, Risk potential and enabling environment. As the survey result shows, the main market participants in wheat value chain are producers, processor, collectors, wholesaler, retailers, and consumers. Based on the wheat VCA 14,074,635.00, 15,191,456.00, 16,653,200.00, 16,279,500.00 and 24,871,230.00 ETB income generated from, Producer, Collectors, Wholesalers, Retailers, Processor and Consumers respectively. It also creates 85,000 employment opportunities in wheat value chain system. In wheat value chain the constraints like Low input availability, Diseases, weeds, low soil fertility, less farmers awareness of improved crop management practices, low price of commodities at harvest time, less bargaining power of farmers in the market, Poor infrastructures and transportation cost, lack of timely and sufficient market information, weak market linkages among value chain actors, Lack of quantity and quality, Lack of capacity and packaging materials are some of the main constraints in wheat value chain actors.
\end{abstract}

Keywords: Wheat, Value Chain Analysis, Dodola District

\section{Introduction}

\subsection{Background on Wheat Value Chain}

Agriculture plays an important role by increasing the growth domestic products (GDP) of the world that accounts $31.3 \%$ [1]; in excess of 60 percent of the world's population depends on agriculture for survival. From this, Latin America and sub Saharan Africa covers the highest percentage (90\%) so that the economy of most African countries is depending on the agriculture. In Ethiopia, it contributes about $43 \%$ of GDP, generates $90 \%$ of export value and supply $70 \%$ of the industrial raw materials for domestic industries [2]. Therefore, the agricultural sector is crucial for the overall performance of the countries economy, especially developing countries like Ethiopia.
Cereal crop production and marketing is highly practiced in the world. According to FAO (3), the total output of cereal crops in 2017 was 2650.5 million tons, which is increased by $2.4 \%$ from previous year; and from these 410.9 million tons of cereal crops in the world were traded in the world cereal markets. In the same year, Africa's contribution to the world output was $7.03 \%$ (about 186.37 million tons) [3]. Cereal grains are the single most important source of calories to a majority of the world population in developing countries like Ethiopia and developed countries. In the Country, cereal production and marketing are the means of livelihood for millions of small holder households and it constitutes the single largest sub-sector in economy. It contributes a great role in its economic growth and development, which creates rural employment opportunities (about 60\%); more than $40 \%$ of a household's food expenditure is covered by the income 
obtained from cereals [4].

Wheat (Triticum aestivum L.) is one of the globally produced and marketed cereal crops, which covers $15 \%$ of the total sowing areas of cereal crops in the world. It is an important industrial and food grain, which ranks second among the most important cereal crops in the world, after rice and traded internationally [5-7].

Wheat production and consumption is grown rapidly as a result of income growth and rapid urbanization in Sub-Saharan Africa (produce $30 \%$ of their domestic requirements) (Sultan, 2016). Ethiopia is the second largest wheat producers in SubSaharan Africa next to South Africa, with a potential expansion to 1.3 million hectare [8]. In Ethiopia, wheat is one of the most cereal crops in terms of the area of land allocated (1.6 million hectares), volume produced (3.9 million tons) and the number of farmers engaged in its production (4.7 million farmers) with a productivity of 2.4tone per hectare [1 and 9]. The highlands of the central, south-eastern and northwest parts of the country are the main wheat growing areas of Ethiopia; and regionally, wheat production comes from Oromia (57.4\%), Amhara (27\%), SNNP (8.7\%) and Tigray (6.2\%) of the national production [1].

However nearly all wheat, except few governments owned large-scale (state) farms and commercial farms produced wheat in the country, is produced under rain-fed conditions predominantly by small scale farmers [10]. Therefore, wheat is the most important cereal crops that need much emphasis on its production and marketing. In Ethiopia, wheat grain is used in the preparation of a range of traditional food products such as the traditional staple pancake ("injera"), fermented bread ("dabo"), non-fermented bread ("hambasha/kitta"), boiled grain ("nifro"), roasted grain ("kolo"), snacks made from bread flour ("dabokolo"), cracked and boiled grain ("kinche"), porridge ("genfo"), local fermented beer ("tella"), distilled local spirit ("areki"), and several other local food items. This shows that wheat is an important market oriented commodity and a major source of income for many wheat growers in Ethiopia; it is crucial for improving their way of life through growing and selling.

\subsection{Statement of the Problem}

Development policy of Ethiopia has placed emphasis on increasing agricultural production to serve as a base for rural development. Even though there has been an increase in agricultural production, there were drawbacks with regards to many households limited participation in the markets. The limited market participation of many agricultural households face is considered to be a major constraint to combating poverty [11]. This shows that an efficient, integrated and responsive market that is marked with good performance is of crucial importance for optimal allocation of resources and stimulating households to increase output [12].

[13] Argue that spatial inefficiency within Ethiopian wheat markets prevents wheat from being transferred from the regions in which surpluses are generated to those in which demand outpaces production. One possible explanation for this failure is that the marketing system lacks the capacity to provide timely and accurate price signals, which present special challenges given the price instability described above.

According to Mohammed Hassena [14] upgrading the wheat market value chains sector takes into account the systematic understanding of the problems and opportunities that exist across the value chain from input supply to marketing of the final product. The major challenge in the wheat value chain and the reason behind supporting this value chain in general is because of the incoming globalization. As the western Arsi Zone is the main source of wheat production area in Ethiopia the absence of adequate information and weak value chain on wheat marketing hinders different actors to benefit more from the existing market channel. So this paper is proposed to show the value chain analysis of wheat in Denaba Kebele, Dodola Districts of West Arsi Zone.

\subsection{Objective of the Paper}

\subsubsection{General Objective}

The general objective of the study is to analyze the wheat value chain in Denaba Kebele, Dodola Districts of West Arsi zone.

\subsubsection{Specific Objectives}

1. To identify the core functions and major actors involved in each value chain.

2. To identify major constraints and opportunities in each value chain.

3. To examine cost benefit analysis in wheat value chain.

4. To analysis what value chain in the study area.

\subsection{Scope and Significance of Wheat Value Chain Analysis}

This study focused on the entire wheat value chain from input supplier to the consumer within Denaba Kebele. The value chain analysis done in one Kebele and important information were collected from some secondary source and memorization of all group member. The paper provides value chain map, challenges, opportunities and entry points in the wheat value chain. In addition, the paper provides information on the wheat market chain, the marketing margin, benefit share of actors, and identifies opportunities and constraints of wheat value chain in the specific area.

The information is expected to have valuable input that helps market participants to understand supply potential and performance of wheat marketing and come up with important recommendations that helps in delivering required efforts to enhance the production and utilization of wheat at larger scale to bring about economic development in the area. The information generated could help development organizations, traders, producers, policy makers, extension service providers, government and non-governmental organizations to assess their activities and redesign their mode of operations in the area.

\section{Literature Review}

\subsection{Definition and Basic Concepts}

Market: The term market has got a variety of meanings. [5] 
Defined markets are places where buyers and sellers come together to trade. [15]. A market according to kohls and Uhl [16] is an arena for organizing and facilitating business activities and for answering the basic economic questions: what to produce, how much to produce, how to produce, and how to distribute production.

Marketing: [17] definition of marketing is widely known as "the 21 century definition of marketing" which runs as follows a social and managerial process by which individuals and groups obtain what they need and want through creating and exchanging products and values with others.

Market channel: The marketing channel is a trade or distribution network and it is defined as sets of interdependent organizations involved in the process of making the product or service available for consumption. The channel follows a vertical structure where products flow from producer to the ultimate consumer and in which actors meet at each market. Different marketers exist in channel arrangements to perform marketing functions that contribute to the product flow.

Marketing chain: Defines follow of commodity from producer to consumers that brings into place economic agents who perform complementary functions with the aim of satisfying both producers and consumers [18].

Marketing system: It is defined as the sequential set of kinds or types of business firms through which a product passes during the marketing process. It is the interrelationship of firms (Branson and [19]. It is usually seen as a "system" because it comprises several, usually stable, interrelated structures that, along with production, distribution, and consumption, underpin the economic process.

Agricultural marketing: is defined as agriculturally oriented marketing. It embraces all operations and institutions involved in moving farm products from farm to consumers. It covers all the activities associated with the agricultural production and food, feed, and fiber assembly, processing, and distribution to final consumers, including analysis of consumers' needs, motivations, and purchasing and consumption behavior [19]. In the process of marketing, buyers and sellers are linked together and can react to current situations of supply and demand. Participants there by generate income which enhances their welfare.

\subsection{Why Value Chain Analysis}

Value chain analysis is a useful analytical tool that helps understand overall trends of industrial reorganization and identify change agents and leverage points for policy and technical interventions. Value chain analysis is the process of breaking a chain into its constituent parts in order to better understand its structure and functioning. The flows of goods, information and finance through the various stages of the chain are evaluated in order to detect problems or identify opportunities to improve the contribution of specific actors and the overall performance of the chain [20]. According to Anandajayasekeram et al. (2009), there are four major key concepts guiding agricultural value chain analysis. These are effective demand, production, value chain governance, and upgrading.

\section{Methodology}

\subsection{Description of the Area}

West Arsi is one of Oromiya Regional state territory which is surrounded by one National regional it shares bounder line with East Shewa zone to the north, SNNPRS to the west and south, Arsi to the northeast, Guji to the south east and Bale zone to the east. Most parts of the zone have elevations of ranging from 1500 to over $3300 \mathrm{~m}$. Shashemene town is the administrative center of the zone it located at $250 \mathrm{~km}$ from Finfine and the total area of Zone is $12556 \mathrm{~km} 2$ West Arsi Zone is located approximately at a distance of $250 \mathrm{~km}$ from Finfine. It is located in the Rift Valley Region The Astronomical location of West Arsi zone lies between 6012'29" to 7042'55" latitude and 38004'04" to 39046'08" longitude. West Arsi Zone has 12 districts, 4 Urban Administrative, 332 peasants association. Deneba Kebela is one of area that belong to under Dodola districts in West Arsi. The area is know with producing wheat, maize, barely, teff and others some highland crops. The agroecology of the area is suitable for those cereal crops.

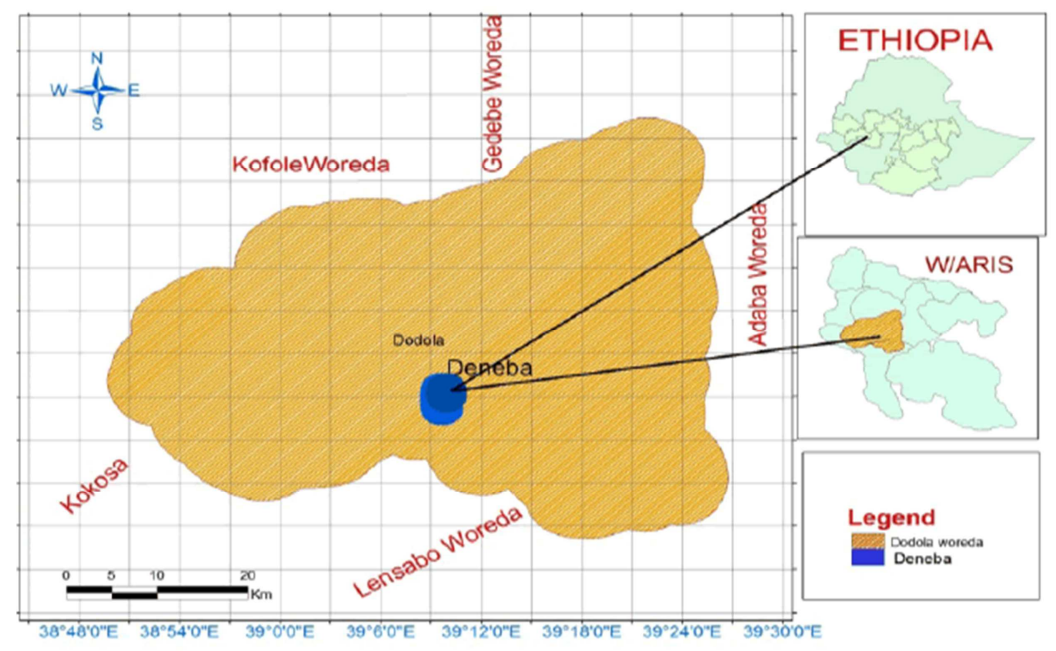

Figure 1. Intervention area. 


\subsection{Methods of Analysis}

This assignment was done by identifying relevant Wheat value chain actors in Deneba Kebele, Dodola Districts of West Arsi Zone. The paper used secondary data and from group member intervention. The data were collected from relevant sources such the CSA, and FAO database, published and unpublished documents. The information collected were analyzed and organized to develop Wheat value chain analysis.

\section{Wheat Value Chain Analysis}

\subsection{Selection Criteria}

In west arsi Zone crops like; Wheat, Maize, Barley, Teff and Len seed are grown with a different farming system. The prioritizing process use by determining and ranking a set of criteria to be used to prioritize the value chains, determining the potential sub-sectors, products or commodities that could be considered, and finally constructing a matrix to enable ranking of the products according to the criteria. To identify the commodity which is first ranking from the other commodities use Food security, Environmental sustainability, Production potential, Market demand, Gender mainstreaming, Risk potential and enabling environment as the main criteria. So, as the below table (1) show that the wheat were ranked at the first level and selected to analysis of value chain in Denaba Kebele, Dodola Districts of West Arsi Zone.

Table 1. Selection criteria from different products.

\begin{tabular}{|c|c|c|c|c|c|c|c|}
\hline \multirow[b]{2}{*}{ № } & \multirow{2}{*}{ Criteria of selection } & \multirow{2}{*}{$\%$} & \multicolumn{5}{|c|}{ List of different commodity } \\
\hline & & & Wheat & Len seed & Barley & Teff & Maize \\
\hline 1 & Food security & 15 & 5 & 1 & 4 & 2 & 3 \\
\hline 2 & Environmental sustainability & 10 & 2 & 2 & 2 & 2 & 2 \\
\hline 3 & Production potential & 15 & 5 & 2 & 4 & 1 & 3 \\
\hline 4 & Market demand & 17 & 5 & 4 & 3 & 3 & 2 \\
\hline 5 & Gender mainstreaming & 14 & 4 & 4 & 3 & 1 & 2 \\
\hline 6 & Risk potential & 14 & 4 & 3 & 2 & 3 & 2 \\
\hline 7 & Enabling environment (Policy) & 15 & 5 & 2 & 3 & 1 & 4 \\
\hline Score & & 100 & 30 & 18 & 21 & 13 & 18 \\
\hline Rank & & & $1^{\mathrm{st}}$ & $3^{\text {rd }}$ & $2^{\text {nd }}$ & $4^{\text {th }}$ & $3^{\text {rd }}$ \\
\hline
\end{tabular}

\subsection{Wheat Value Chain Actors and Their Role}

Marketing actors are those who participate in production, processing, transporting, and marketing of wheat in the cereal markets. The chain actors can be categorized as direct/main actors (actors who are directly participated in the market chain) and indirect/supportive actors (actors who provide supports to the main actors either financially or nonefinancially). The main actors in the chain include producers, processor, Collectors, wholesaler, retailers, and consumers whereas the indirect actors are financial institutions, governments, NGOs.

\subsubsection{Producers}

Producers are major actors who perform most of the value adding functions. These are the main actors who participate in the production of wheat; and are the first link in the wheat market chain. The functions include: land preparation, planting, applying fertilizer, weeding, pest/disease controlling, harvesting and post-harvest handling. The main roles of the producers are producing the wheat produce and sell to the next actors in the nearest markets. Producers are supplying and selling their produce to the next different actors (either to processor or wholesaler or retailer or consumer etc.) since they are the first link in wheat market chain.

\subsubsection{Collectors/Assemblers}

Collectors are part time producers or non-licensed traders who collect wheat from producers at village/town markets for the purpose of reselling to wholesalers. The collectors in some situations acted as the first link between producers and other traders. Collectors use their local knowledge to bulk wheat from the surrounding area. They play important role due to their knowledge of areas of surplus wheat and cheaper prices. The trading activities of collectors include buying and assembling, repacking, sorting, transporting, and selling to wholesalers.

\subsubsection{Retailer}

Retailers are businesses that sell the wheat to the end user according to requirement and purchasing power of the buyer. They often trade wheat purchased from wholesalers, urban assemblers and producers and mostly they operate in producer near-markets. As the last link between producers and consumers, retailers were key actor in wheat value chain.

\subsubsection{Wholesalers}

These are licensed wheat traders who bulk and assemble wheat in their permanent store at market places and may or may not move from one market to another to buy and resale grains. They bought wheat directly from the producers in the market and some used to buy wheat from other district markets and brought to resale. They had better storage, transport, and communication access than other traders. Almost all wholesalers have a warehouse in a market either self-owned or rental basis.

\subsubsection{Processors}

Wheat processer converts wheat into wheat flour and barn, flour into biscuits, pasta, macaroni and bread that add value to the product and to satisfy market requirement. Wheat 
processer purchase domestically produced wheat at market price from traders and farmers, and imported wheat at subsidized price from government. They sell former one to wholesalers and retailers at market price and distribute later one to bakeries at subsidized fixed price.

\subsubsection{Consumers}

The ultimate beneficiaries of the product, it has been through processed and unprocessed products. Those, who bought wheat and its products for consumption at household level.

Table 2. Mapping of specific activities undertaken by actors.

\begin{tabular}{|c|c|c|c|c|c|c|}
\hline & Input provision & Production & Collection & Wholesale & Retail & Consumer \\
\hline Actor & $\begin{array}{l}\text { Raya wakena farmer cooperative union, } \\
\text { Oromia seed enterprise, bureau of } \\
\text { agriculture, Cooperative promotion } \\
\text { agency, Research institute, University, } \\
\text { NGOs/Projects }\end{array}$ & $\begin{array}{l}\text { Small holder farmers } \\
\text { Private commercial } \\
\text { farms } \\
\text { Cooperatives }\end{array}$ & $\begin{array}{l}\text { Local traders } \\
\text { and primary } \\
\text { cooperatives, }\end{array}$ & Urban and rural wholesalers & $\begin{array}{l}\text { Urban and } \\
\text { rural } \\
\text { retailers }\end{array}$ & \\
\hline Activities & $\begin{array}{l}\text { Agriculture input supply (fertilizer, seeds, } \\
\text { chemicals), technical support }\end{array}$ & $\begin{array}{l}\text { Cultivation of wheat } \\
\text { grain }\end{array}$ & $\begin{array}{l}\text { Collection of } \\
\text { wheat grain }\end{array}$ & $\begin{array}{l}\text { In bulk collection, sale to mill } \\
\text { factory, retailers, bakery, } \\
\text { restaurant, and consumers }\end{array}$ & $\begin{array}{l}\text { Retail to } \\
\text { consumers }\end{array}$ & \\
\hline
\end{tabular}

\subsection{Wheat Market Value Chain Map}

The marketing channel is a trade or distribution in the process of making the product or service available for consumption. One of the most important and core for analyzing value chain system is value chain mapping. Value chain mapping means drawing of the visual representation of the value chain system. Maps identify business operations (functions), chain operators and their linkages, as well as the chain supporters within the value chain. Quantifying and describing value chains in detail includes attaching numbers to the basic chain map, e.g. numbers of actors, the volume of produce or the market shares of particular segments in the chain. Mapping market channels functions facilitates a clear understanding of the sequence of activities and the key actors and relationships involved in the value chain. Based on the analysis had been conducted, the wheat value chain presented in the following approach.

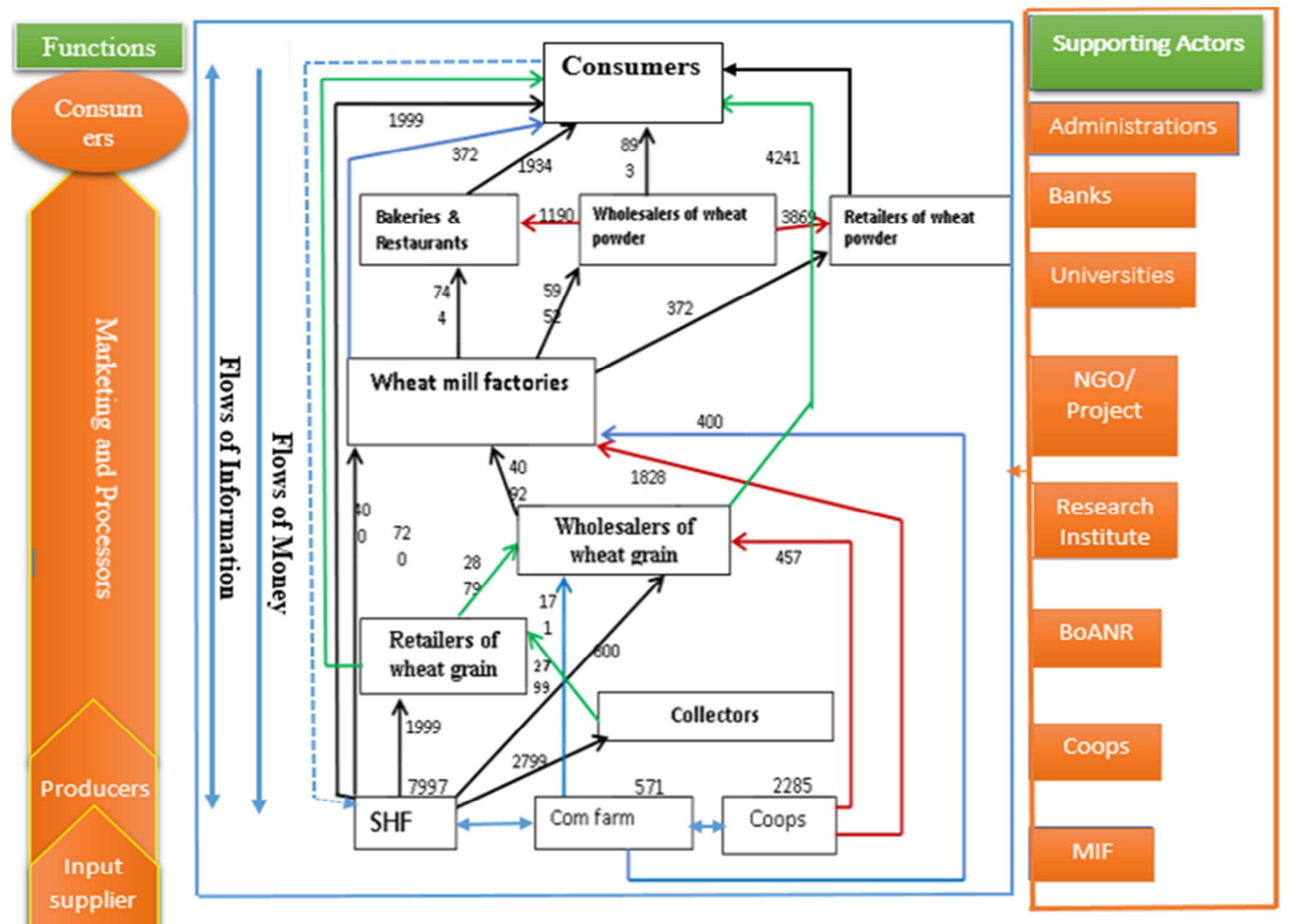

Figure 2. Wheat Value chain Map. 
From the above wheat value chain the major eleven identified market channels in both before and after processing in the system.

Channel 1: Producer-Consumer

Channel 2: Producer-Retailer-Consumer

Channel 3: Producer- Wholesaler-Consumer

Channel 4: Producer-Collector-Retailer-Consumer

Channel 5: Producer-Wheat mill factories-Consumers

Channel 6: Producer-retailer-Wholesaler of powder-Wheat mill factories -Consumers

Channel 7: Producer- Wholesaler-Wheat mill factories- Consumers

Channel 8: Producer- Collector-Retailer-WholesalerWheat mill factories-Consumers
Channel 9: Producer - Wheat mill factories-Bakeries \& Restaurants-Consumers

Channel 10: Producer -Wheat mill factories- Wholesalers of wheat powder -Consumers

Channel 11: Producer-Wheat mill factories- Retailers of wheat powder--Consumers.

\subsection{Geographical Flow of Wheat Product}

The flow of the wheat production starts from Denaba Kebele, Dodola Districts of West Arsi Zone. In the system of value chain the processed and the wheat grain move from selected area to other place in different ways. The below map Indicate where the flow of wheat production starts and reach.

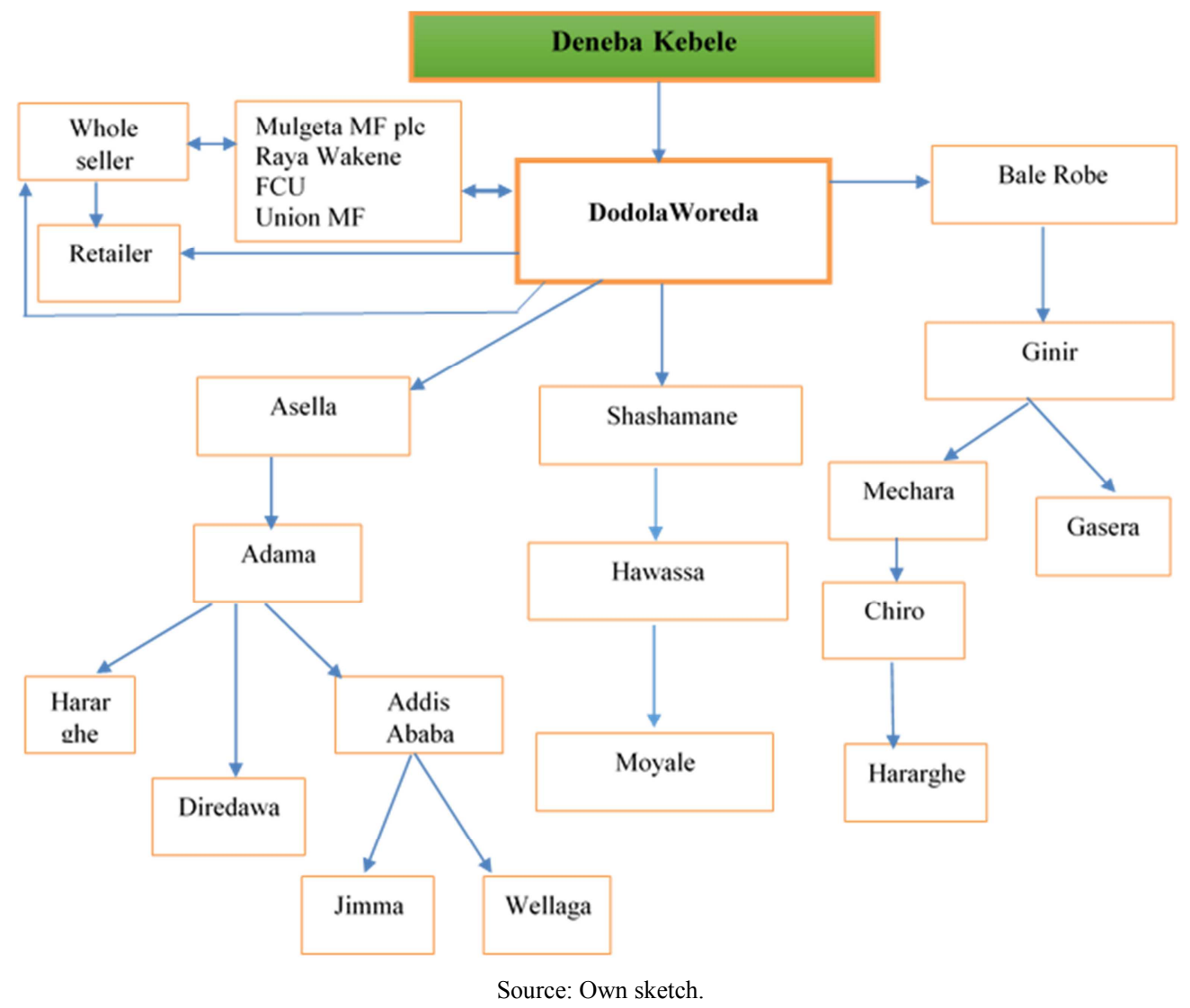

Figure 1. Geographical flow of wheat product.

\subsection{Cost Benefit Analysis of Wheat Value Chain Per Quintal in Birr (ETB)}

In the selected area a total of $238 \mathrm{ha}$ of land used to produce wheat. Productivity potential is 48 quintal/ha.

Table 3. Cost benefit analysis.

\begin{tabular}{|c|c|c|c|c|c|c|c|c|c|c|c|}
\hline \multirow{2}{*}{ Cost item } & \multicolumn{2}{|c|}{ Producer cost } & \multicolumn{2}{|c|}{ Collectors cost } & \multicolumn{2}{|c|}{ Retailers cost } & \multicolumn{2}{|c|}{ Wholesalers cost } & \multicolumn{3}{|c|}{ Processor cost } \\
\hline & Total & per qut & Total & Per qut & Total & per qut & Total & Per qut & Total & per qut & Consumers \\
\hline Labor & $21,563.00$ & 1.89 & $20,200.00$ & 1.86 & $27,133.00$ & 2.50 & $32,559.00$ & 3.03 & $50,199.00$ & 4.67 & $53,870.00$ \\
\hline Fertilizers & $531,100.00$ & 46.49 & 0.00 & 0.00 & 0.00 & 0.00 & 0.00 & 0.00 & 0.00 & 0.00 & 0.00 \\
\hline Chemicals & $31,284.00$ & 2.74 & 0.00 & 0.00 & 0.00 & 0.00 & $20,349.38$ & 1.89 & 0.00 & 0.00 & 0.00 \\
\hline Transport & $20,125.00$ & 1.76 & $32,559.00$ & 3.00 & $32,559.00$ & 3.00 & $92,371.00$ & 8.60 & $16,341.00$ & 1.52 & $75,418.00$ \\
\hline Sack & $108,530.00$ & 9.50 & $108,530.00$ & 10.00 & $108,530.00$ & 10.00 & $107,740.00$ & 10.03 & $205,782.00$ & 19.15 & $43,096.00$ \\
\hline Storage & 0.00 & 0.00 & 0.00 & 0.00 & 0.00 & 0.00 & $37,985.50$ & 3.54 & $10,774.00$ & 1.00 & 0.00 \\
\hline
\end{tabular}




\begin{tabular}{|c|c|c|c|c|c|c|c|c|c|c|c|}
\hline \multirow{2}{*}{ Cost item } & \multicolumn{2}{|l|}{ Producer cost } & \multicolumn{2}{|l|}{ Collectors cost } & \multicolumn{2}{|l|}{ Retailers cost } & \multicolumn{2}{|c|}{ Wholesalers cost } & \multicolumn{3}{|l|}{ Processor cost } \\
\hline & Total & per qut & Total & Per qut & Total & per qut & Total & Per qut & Total & per qut & Consumers \\
\hline Electricity & 0.00 & 0.00 & 0.00 & 0.00 & 0.00 & 0.00 & 30.00 & 0.003 & $3,000.00$ & 0.28 & 0.00 \\
\hline Grading & 0.00 & 0.00 & 0.00 & 0.00 & 0.00 & 0.00 & $65,118.00$ & 6.06 & $23,675.00$ & 2.20 & 0.00 \\
\hline Sorting/cleaning & $22,536.00$ & 1.97 & 0.00 & 0.00 & 0.00 & 0.00 & $21,706.00$ & 2.02 & 0.00 & 0.00 & 0.00 \\
\hline Packaging & 0.00 & 0.00 & $3,000.00$ & 0.28 & 500.00 & 0.05 & $3,000.00$ & 0.28 & $15,923.00$ & 1.48 & 0.00 \\
\hline Mill factory & 0.00 & 0.00 & 0.00 & 0.00 & 0.00 & 0.00 & 0.00 & 0.00 & $200,000.00$ & 18.62 & 0.00 \\
\hline Total cost in ETB & $1,062,863.00$ & 93.04 & $165,539.00$ & 15.25 & $170,422.00$ & 15.70 & $383,858.88$ & 35.73 & $527,794.00$ & 49.12 & $172,384.00$ \\
\hline Yield potential qut./hac & 48 & & & & & & & & & & \\
\hline Volume of produce & 11424 & & 10853 & & 10853 & & 10744 & & 10235 & & 0 \\
\hline Wheat straw (ETB) & $15,960.00$ & 0.00 & 0.00 & 0.00 & 0.00 & 0.00 & 0.00 & 0.00 & 0.00 & 0.00 & 0.00 \\
\hline Feed (wheat bran) qtl & 0 & & 0 & & 0 & & 0 & & 539 & & 539 \\
\hline Consumed & 571 & & 0 & & 0 & & 0 & & 0 & & 10235 \\
\hline Price/qtl. (ETB) & $1,200.00$ & & $1,250.00$ & & $1,310.00$ & & $1,400.00$ & & $2,000.00$ & & $2,490.00$ \\
\hline feed (wheat bran) ETB & 0.00 & & 0.00 & & 0.00 & & 0.00 & & 470.00 & & 595.00 \\
\hline Total revenue in ETB & $13,039,560.00$ & $1,201.47$ & $13,566,250.00$ & $1,234.75$ & $14,217,430.00$ & $1,294.30$ & $15,041,600.00$ & $1,364.27$ & $21,801,330.00$ & $1,974.39$ & \\
\hline Net income (profit) & $11,976,697.00$ & 1.47 & $13,400,711.00$ & 34.75 & $14,047,008.00$ & 44.30 & $14,657,741.12$ & 54.27 & $21,273,536.00$ & 574.39 & \\
\hline Rank by profit & $5^{\text {th }}$ & & & & & & $4^{\text {th }}$ & & $1^{\mathrm{st}}$ & & \\
\hline Margin & & & $1,424,014.00$ & & $646,297.00$ & & $610,733.12$ & & $6,615,794.88$ & & \\
\hline
\end{tabular}

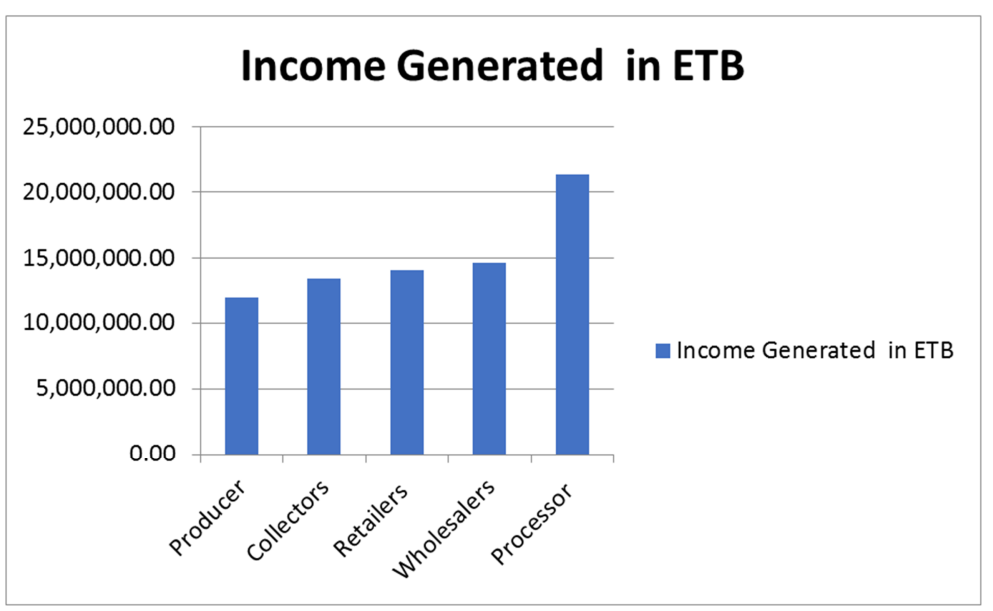

Figure 4. Income generated in Wheat value chain system.

Based on the above graph the more income is generated by the processors and the less income generated by Wheat producers. This shows that there is high cost in wheat producers than the other actors in the value chain. From this we have concluded that there is no equity in the distribution of values added from one actor to the other actors.

\subsection{Value Added and Employment Creation Among at Different Value Chain Actors}

Table 4. Value added and employment creation.

\begin{tabular}{llll}
\hline № & Value chain actors (Main actors) & Value added & Employment creation in the wheat value chain (in number) \\
\hline 1 & Producer & -Cleaning, Sorting & 30,000 \\
2 & Collector & -Packing & 10,000 \\
3 & Retailers & -Packing & 6000 \\
4 & Wholesalers & -Grading, Cleaning, Sorting, Storing, & 4000 \\
5 & Processer & -Grading, Packing, Processing to powder, storing & 35,000 \\
Total & & 85,000 \\
\hline
\end{tabular}

\subsection{Major Constraints and Opportunities in Wheat Value Chain}

\subsubsection{Constraints of Wheat Value Chain}

Factor affecting wheat production and marketing sector takes into account the systematic understanding of the problems that exist across the value chain from input supply to marketing of the final product which affects value addition at different stages. Major wheat production constraints include; diseases, weeds, low soil fertility, shortage/unavailability of seed of improved variety, less farmers awareness of improved crop management practices, high cost of combine harvesting since the area wheat produce farmers follow mechanized wheat production system, lack of credit, less availability and efficacy of many pesticides available in the market, untimely supply of fertilizers and 
shortage of capital to buy farm inputs and high price of seeds, chemical fertilizers and pesticides were the factors that affected production and productivity of wheat in the area.

The major marketing constraints faced the farmers and traders is unfair pricing and cheating of traders on balance; lack of timely and sufficient market information; Market infrastructure and Transportation cost; low price of commodities at harvest time; weak market linkages among value chain actors and less bargaining power of farmers in the market. There are also regular market fluctuations, different quality problems and shortage of storage facilities in addition to poor transportation. Processors main challenges were lack of uniformity in quality of flour for bread, cakes and cookies all which do not have standards established for them. There are also high production costs relative to selling price, unstable prices of flour, unfair competition from illegal traders and finally frequent electric power and water interruptions were also the main constraint.

There are also quality problem due to poor weeding and inferior harvest management techniques. In addition to this, rain during the harvesting period sometimes spoils large volumes of grains. The small scale farmer does not have an insurance mechanism that safeguards its harvest from natural hazards, such as unwanted rain. Due to the above problems farmers supply different quality products to actors involved in wheat business in the area.

Table 5. Constraints in wheat value chain.

\begin{tabular}{|c|c|}
\hline Value chain stages & Major Bottlenecks (Constraints) \\
\hline \multirow{2}{*}{ In input supply stage } & 1. Low input availability \\
\hline & 2. Low knowledge of farmers to use improved input \\
\hline \multirow{7}{*}{ Production stage } & 1. Diseases, weeds, low soil fertility, \\
\hline & 2. less farmers awareness of improved crop management practices \\
\hline & 3. lack of excess land and working capital \\
\hline & 4. low extension service \\
\hline & 5. High price and low availability of improved seed, fertilizer and chemical \\
\hline & 7. low price of commodities at harvest time \\
\hline & 8. less bargaining power of farmers in the market \\
\hline \multirow{6}{*}{ Marketing } & 1. Poor infrastructures and transportation cost \\
\hline & 2. lack of improved storage facility \\
\hline & 3. lack of transportation facilities \\
\hline & 4. unfair pricing and cheating of traders on balance \\
\hline & 5. lack of timely and sufficient market information \\
\hline & 6. weak market linkages among value chain actors \\
\hline \multirow{3}{*}{ Processing } & 2. Lack of supply and infrastructure \\
\hline & 3. Lack of capacity and packaging materials \\
\hline & 4. Weak distribution channels \\
\hline \multirow{2}{*}{ Consumption } & 1. High price and low quality \\
\hline & 2. Low availability in terms of quantity, quality and size \\
\hline
\end{tabular}

\subsubsection{Opportunity in Wheat Value Chain}

Despite the considerable constraints listed above, there are many opportunities for the wheat value chains actors in the area. The potential marketing opportunities of the area are the buildup of good road that connects other zone market to different towns in the country which creates potential demand for the products produced in the area. Furthermore, the increasing food processing plants in and around the area is creating additional demand for the Wheat commodities. Consequently, this contributes for commercialization of rural economy and creates many off-farm jobs opportunities. Furthermore, provision of infrastructure facilities like telecommunication, power supply and financial institutions (Banks, Micro-Finance) supports the marketing activities in the area.

The interest of farmers in improved varieties; the availability of market for the crop; strong interest of national and international research organizations in the Wheat improvement; the importance of the crop in food selfsufficiency as strategic crop at regional and national levels; the diverse use value of the crop; availability of various processing plants for various products; and availability of human resource and knowledge in the improvement and development of the crop are some of the major opportunities available for the crop improvement and expansion of its production in the area.

\subsection{Intervention Strategies}

For improving the wheat value chain in the area implementing different intervention strategies are important based on the constraint face in overall chain actors. The following are some of the intervention that help to make the wheat value chain strong in all system.

i. Improve the infrastructure, market linkage and information flow

ii. Provide input services such as improved seed and fertilizers

iii. Demonstration services on wheat production and management practices

iv. Provision of credit service for smallholder farmers to improve wheat production

v. Provision of training for all producers that help to maintain the quality product and to satisfy customer need 
vi. Processors help and share the information to other actors vii. Ensuring the equity in value addition for each actor

viii. From the consumer side it is also good to have consumer-targeted awareness movement's activities to use in sustainable manners.

ix. Improved linkages between Agricultural sector, researchers and farmers play a vital role in improving the supply of technological packages and the necessary tools to disseminate information generated to the various actors.

\subsection{Governance of the Product}

i. To increase the price of wheat products in the area producers have make an improvement in the production process

ii. To increase quality of wheat producers have to use improved variety and management

iii. There must be smooth information and knowledge flow across all actors to increase trust.

iv. Interdependency between all actors to equally govern and share equal profit.

v. Actors would to be provided with appropriate scale of training based on the quality of wheat concerned

vi. Like collectors should be equipped with the necessary wheat handling and management knowledge.

vii. Put appropriate price based on the wheat quality and verity

viii. Giving training on the wheat disease protection

ix. Processors, on the other hand, must be offered short term technical assistance to improve their business and marketing skill

x. Quality improvement and Support service for new product development.

\subsection{Assumptions}

The assumptions are putted for wheat value chain as the following;

i. Increase the productivity of small producers and increase their income.

ii. Transfer subsistence Farmers to semi-commercial farmers

iii. Create job opportunities for smallholders

iv. Link the farmers to market

v. Improve food security

vi. Mutual inclusive for all groups of society

\section{Five Years Strategic Plan to Increase Wheat Productivity}

Table 6. Five year's Strategic plan.

\begin{tabular}{|c|c|c|c|}
\hline № & Annual target & Baseline & Achievement of 5 year \\
\hline 1 & Increase productivity & 48qtl/ha & $55 \mathrm{qtl} / \mathrm{ha}$ \\
\hline 2 & $\begin{array}{l}\text { To improve income of } \\
\text { House hold }\end{array}$ & $15,187,200.00 \mathrm{ETB}$ & $17,402,000.00$ ETB \\
\hline 3 & $\begin{array}{l}\text { To increase employment } \\
\text { opportunity }\end{array}$ & 180 & 900 \\
\hline
\end{tabular}

\section{Conclusion and Recommendation}

\subsection{Conclusion}

Ethiopia is the second largest wheat producers in SubSaharan Africa next to South Africa, with a potential expansion to 1.3 million hectare. The highlands of the central, southeastern and northwest parts of the country are the main wheat growing areas especially west Arsi zone including Deneba Kebele. The main market participants in wheat value chain are producers, processor, collectors, wholesaler, retailers, and consumers. The wheat commodity selected based on use Food security, Environmental sustainability, Production potential, Market demand, Gender mainstreaming, Risk potential and enabling environment. Based on the wheat value chain analysis 14,074,635.00, 15,191,456.00, 16,653,200.00, $16,279,500.00$ and 24,871,230.00 ETB income generated from, Producer, Collectors, Wholesalers, Retailers, Processor and Consumers respectively. It also creates 85,000 employment opportunities in wheat value chain system. This indicate that wheat producers gain low revenue than the other actors in the value chain.

In wheat value chain Low input availability, Diseases, weeds, low soil fertility, less farmers awareness of improved crop management practices, low price of commodities at harvest time, less bargaining power of farmers in the market, Poor infrastructures and transportation cost, lack of timely and sufficient market information, weak market linkages among value chain actors, Lack of quantity and quality, Lack of capacity and packaging materials are some of the main constraints in wheat value chain actors.

\subsection{Recommendation}

From the above wheat value chain analysis, the following recommendation are forwarding to concerned body;

Improvement of access to credit for wheat market participants: many traders and farmers are not entering the wheat market because of the absence of enough initial capital and collaterals. Therefore, the credit access should be improved to enable them to participate in the market.

Improving access to wheat market information and infrastructure: having market information plays a great role in improving the efficiency and effectiveness of wheat market chain. But, many farmers do not have market information. Therefore, facilitating and improving the quality and types of market information delivery used by farmers shall take policy attention. In addition to this due to lack of market infrastructure, wheat producer farmers are not participating in the market. Therefore, the government should build market infrastructure to improve the marketing and marketing system of wheat in the areas as well in the country.

Strengthening the extension service: Access to extension services affects the probability of participating in value addition and participation as well faire utilization from the chain. It also enables flow of information and transfer of knowledge and scientific findings to practice that will help all actor especially small holder farmers in production of 
value added products. Therefore, strengthening agricultural extension services should be considered as important input for producing value added products and help to penetrating producer in the market system.

Providing training service and Enhance wheat producer bargaining power: The enhancement of wheat producers' bargaining power through cooperatives is the best measure that should target increasing farmer's share of benefit from his marketable produce. In order to solve shortage of improved varieties seed, improving farmers' knowledge in quality seed production through training is important. Improving knowledge of farmers on production of quality seed by themselves will solve shortage problem and save expenditures incurred by farmers.

\section{Acknowledgements}

The authors would like to express their appreciation to Southern Agricultural Research Institute and Areka Agricultural Research Center for the financial support and Jimma University College of Agriculture and Veterinary Medicine for their logistic support for this study.

\section{References}

[1] CIA, the World Fact Book, 2014. ETHIOPIA, Available on: https://www.cia.gov/library/publications/theworldfactbook/geos/et.html\#Econ.

[2] Abdu Mohammed, Melkamu Bazea, Mohammed Ahmed, 2016. Smallholder Commercialization and Commercial Farming in Coffee-Spice Based Farming System of South West Ethiopia, International Journal of Research Studies in Agricultural Sciences (IJRSAS) Volume 2, Issue 5, 2016, PP 13-26.

[3] FAO, 2017. Crop Prospects and Food Situation: Quarterly Global Report in United States.

[4] Rashid, S., 2010. Staple Food Prices in Ethiopia. A paper prepared for the COMESA policy seminar on Variation in staple food prices: Causes, consequence, and policy options $\|$, Maputo, Mozambique, 25-26 January 2010, under the African Agricultural Marketing Project (AAMP).

[5] FAO, 2009. Agricultural commodities: profiles and relevant WTO negotiating issues, 2009. Retrieved fromhttp://www.fao.org/docrep/006/y4343e/y4343e02.htm\#To pOfPage.).

[6] Najafi, A. 2014. Wheat production price performance prediction in the Iranian north province. African Journal of Agricultural Research, 9 (1), 74-79.
[7] Falola, A., Achem, B. A., Oloyede, W. O. and Olawuyi, G. O., 2017. Determinants of Commercial Production of Wheat In Nigeria: A Case Study Of Bakura Local Government Area, Zamfara State. Trakia Journal of Sciences, 15 (4).

[8] Haregewoin, T., Belay, B., Bezabeh, E., Kelemu, K., Hailu, D. and Daniel, F., 2018. Impact of Improved Wheat Variety on Productivity in Oromia Regional State, Ethiopia.

[9] ATA, 2014. Agricultural Transformation Agency.

[10] Demeke, M., and Di Marcantonio F. 2013. Analysis of incentives and disincentives for wheat in Ethiopia. Technical notes series, MAFAP, FAO, and Rome.

[11] Best, R., Ferris, S. and Schiavine, A. 2005. Building linkages and enhancing trust between small-scale rural producers, buyers in growing markets and suppliers of critical inputs. In: F. R. Almond and S. D. Hainsworth (eds.). Beyond agriculture-making markets work for the poor: Proceedings of an international seminar. Westminster, London, UK. 176p.

[12] FAO (Food and Agricultural Organization). 2003. FAO action program for the prevention of food loses. Milk and dairy products, post-harvest loses and food safety in sub- Saharan Africa and the near east. Regional approaches to national challenges. Synthesis report. ILRI, Nairobi, Kenya.

[13] Negassa, A., Myers, R., and Gabremadhin, E. 2004. Grain marketing policy changes and spatial efficiency of maize and wheat markets in Ethiopia.

[14] Mohammed Hassena. 2009. Value Chain Analysis for Developing Rural Agri-Business: Value Chain Concept and Its Application to Wheat in Ethiopia. Proceedings of the Value Chain Seminar: Addis Ababa, Ethiopia. P 75-80.

[15] Larson, A. L. 1957. Agricultural Marketing. Prentice-Hall. New York, USA.

[16] Kohl, R. L. and Uhl, J. N., 1985, Marketing of Agricultural Product, 5th Edition, Collier Macmillan, USA. 624p.

[17] Kotler, P. and Armstrong, G. 2003. Principle of Marketing, 10th Edition. Hall of India Pvt. Ltd., New Delhi. pp 5-12.

[18] . Islam, M. S., Miah, T. H. and Haque, M. M., 2001. Marketing system of marine fish in Bangladesh. Bangladesh Journal of Agricultural Economics. 24, (1 and 2): 127-142.

[19] Norvell, N. 1983. Introduction of Agricultural Marketing, McGraw Hill Book Company, New York. 365p.

[20] UNIDO (United Nations Industrial Development Organization). 2009. Agro-value chain analysis and development. The UNIDO approach; A staff working paper, Vienna. 